\title{
WAVE OVERTOPPING SIMULATOR TESTS IN VIET NAM
}

\author{
Le Hai Trung ${ }^{1}$, Jentsje van der Meer ${ }^{2}$, Gerrit Jan Schiereck ${ }^{3}$, Vu Minh Cat ${ }^{4}$, Gerben van der \\ Meer 5 .
}

\begin{abstract}
Sea dikes in Viet Nam have been built up during a long history. Every year, about 4 to 6 storms attack the coast and cause severe damages of the sea dikes. Till now, little is known about strength and stability of the inner slope covered with grass under impacts of wave overtopping during storm surges. Destructive tests have been performed with the Wave Overtopping Simulator in Viet Nam revealing that grass slopes are able to withstand a certain amount of wave overtopping. In Hai Phong, a slope section covered by Vetiver grass could suffer a maximum wave overtopping discharge of up to 120 1/s per m. In Nam Dinh, three tested locations within a short dike section of $50 \mathrm{~m}$ show a large variation in erosion resistance of the Bermuda grass slope with maximum discharge of 20, 40 and $701 / \mathrm{s} \mathrm{per} \mathrm{m}$.
\end{abstract}

Keywords: discharge; erosion; grass; wave overtopping simulator; soil; wave overtopping

\section{INTRODUCTION}

\section{Sea dikes in Viet Nam}

The coastline of Viet Nam is protected by systems of sea dikes with a total length of about 2700 $\mathrm{km}$ from North to South. The sea dike systems have been built manually for a long time and mainly based on accumulated experience. Basically, the dike is a body of soil and the crest and seaward slope are armoured with quarry stones (traditionally) and concrete blocks (recently), while the inner slope is often covered with grass. In general, dike crests are insufficiently high to prevent overtopping during storm surges or even in high tide. Every year, there are on average 4 - 6 typhoons attacking Viet Nam resulting in considerable damages. A large number of sea dike failures have been initiated from damages induced by wave overtopping on the dike crest and inner slope. For example, in a safety assessment of the Hai Hau sea dike system, Mai Van (2010) proved that overtopping is the most likely to occur with $46 \%$ contribution of the total failure probability. Till now, little is known about the strength and stability of inner slopes of sea dikes in Viet Nam under impacts of wave overtopping. With present situation of sea dikes in Viet Nam, overtopping discharges varying roughly in range of 30 and $300 \mathrm{l} / \mathrm{s}$ per $\mathrm{m}$ (Le et al. 2008). According to the present guideline, no value of allowable overtopping discharge can be found as the dike crest level is designed with regard to wave run-up. The remaining issue is the critical value of the wave overtopping discharge on sea dikes in Viet Nam. Therefore the strength of real dikes against wave overtopping needs to be estimated or tested.

The phenomenon of wave overtopping on sea dike has been understood sufficiently, see Eurotop 2007 and other works of Strüttrumpf and Van Gent (2003) and Bosman (2007). While effects of overtopping waves on the structures have been not studied fully, mainly due to the fact that these effects can not be studied in a small wave flume as it is impossible to scale down properties of either soil or grass. Therefore, a device which can simulate wave overtopping tongue on the dike crest was developed in the Netherlands (Van der Meer et al. 2006, 2007, 2008 and 2009).

\section{The Wave Overtopping Simulator}

The Wave Overtopping Simulator is a water tank which can be easily moved from place to place. The Simulator is continuously filled with a certain and constant discharge of water and is emptied at predefined moments through two butterfly valves at the bottom in a way that the volumes simulate the overtopping wave tongues on the dike crest and then on the landward slope. Figure 1 illustrates the principle of the Simulator and how it operates on site. As long as the velocity and the depth of the flow released from the simulator are similar to those in reality on the dike crest, the flow behaviour on the landward slope will then automatically follow.

The first Simulator was designed and then made in the Netherlands. With the experience of testing for a couple of years, the original design was adjusted and improved to make the second Simulator in

\footnotetext{
${ }^{1}$ Faculty of Marine and Coastal Engineering, Water Resources University, 175 Tay Son, Dong Da, Ha Noi, Viet Nam

2 Van der Meer Consulting bv, Voorsterweg 28, 8316 PT Marknesse, The Netherlands

${ }^{3}$ Faculty Civil Engineering \& Geosciences, Delft University of Technology, Stevinweg 1, 2628 CN Delft, The Netherlands

${ }_{5}^{4}$ Faculty of Marine and Coastal Engineering, Water Resources University, 175 Tay Son, Dong Da, Ha Noi, Viet Nam

${ }^{5}$ Private mechanical engineer, the Netherlands
} 
Viet Nam. The maximum unit volume is $5.5 \mathrm{~m}^{3}$ per $\mathrm{m}$ of width, $22 \mathrm{~m}^{3}$ for the Simulator of $4 \mathrm{~m}$ wide. With this size a mean wave overtopping discharge of $75 \mathrm{l} / \mathrm{s}$ per $\mathrm{m}$ can be simulated. The machine is divided into two parts horizontally to fit into 24 feet container, which is more convenient for shipping. The open width of the butterfly valve is $0.8 \mathrm{~m}$ to simulate the correct speed of releasing water, giving good simulation of the water overtopping on the dike crest. The hydraulic pump for opening and closing the vales and the control box are attached to the machine body. The height of the Simulator can be adjusted by six hydraulic legs. Two water pumps with capacity of 22 and $55 \mathrm{~kW}$ respectively were used to fill the Simulator. Last but not least, a $250 \mathrm{kVA}$ generator supplied electrical to all devices and equipments on site.
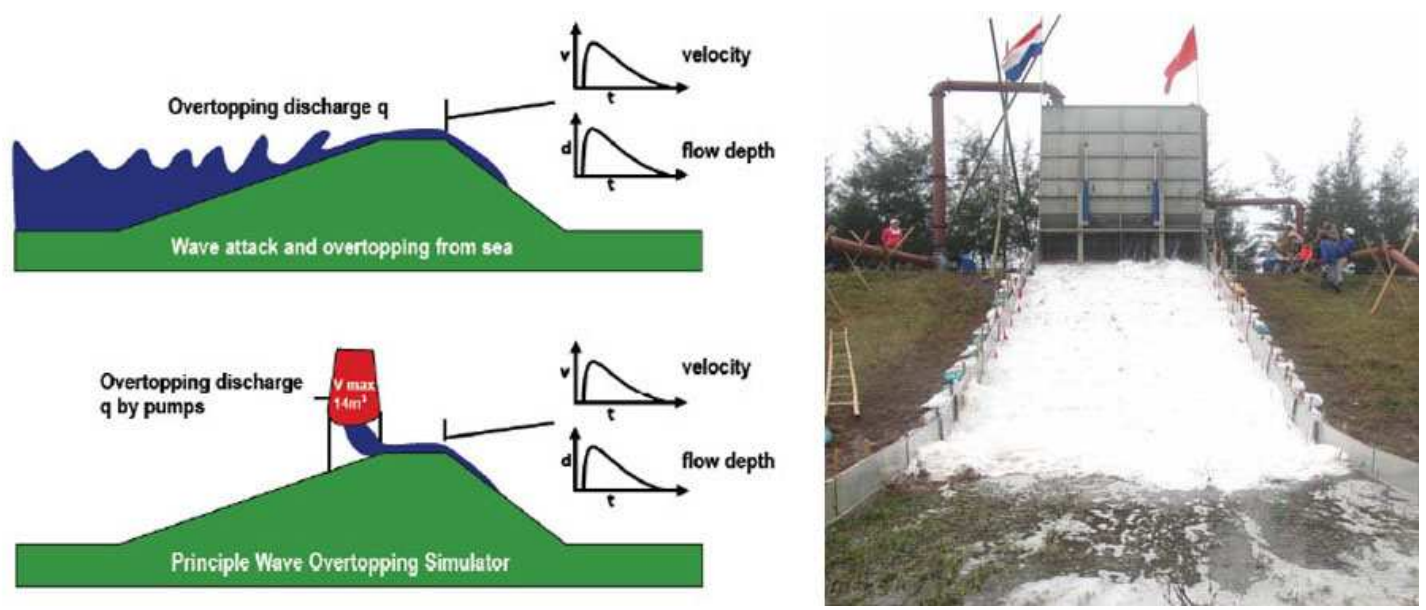

Figure 1. Left: principle of the Wave Overtopping Simulator. Right: overtopping flow released from the Simulator.

Wave overtopping can cause damage of the crest and the landward slope. In principle, two different failure mechanisms can be distinguished. Fast overtopping flow can damage the surface of the crest and the landward slope, if initial damage or erosion occurs, it can extend to the underneath material layer which eventually may lead to dike breaching. This failure mechanism is simulated by the Simulator: slope erosion. The second mechanism that mainly takes place on steep slopes, especially 1:1.5 and 1:2.0, is slip failure. These sliding failures may directly cause a dike breach. Simulator tests do not aim to simulate these failures as a slip failure needs a longer dike section to develop than the $4 \mathrm{~m}$ wide gate through which water is released on the dike slope. In that case a $30 \mathrm{~m}$ long perforated tube on top of the crest, releasing 1 1/s per m constant flow, may induce this slip failure. Such tests have been performed in the Netherlands, but not yet in Viet Nam.

\section{TEST LOCATIONS AND TEST PROGRAMME}

\section{Test locations}

So far, destructive tests have been performed at two different sea dikes in Hai Phong and Nam Dinh in the North of Viet Nam. Locations for Wave Overtopping Simulator tests were selected to satisfy operational requirements and test requirements. Operation requires test locations convenient for transportation such that heavy trucks and a 25 ton crane can easily approach the sites. Besides, a crest width not smaller than $4 \mathrm{~m}$ is required for all devices and equipments such as Simulator, generator, pumps, etc. The Simulator was designed for testing the strength of grass slopes and therefore the dike slope or a part of it must be covered with grass. A water source which can be a canal or pond close to the sea dike is necessary to supply water for testing.

In three years 2008, 2009 and 2010 several fieldtrips were carried out along the coastline of Hai Phong and Nam Dinh in order to select suitable test locations. Dike route No.1 in Do Son - Hai Phong was chosen to perform the pilot test in May 2009. The dike is reinforced with concrete on three parts: seaward slope, dike crest, upper part of the landward slope and the inner berm. Only the lower part of the landward slope was covered with vetiver grass (Vetiveria Zizanioides). The dike crest level is at $+5.2 \mathrm{~m}$ above MSL and the crest width is $7.5 \mathrm{~m}$. The inner berm is at $+3.5 \mathrm{~m}$ above MSL and $5.0 \mathrm{~m}$ wide. The inner slope inclination is $1: 2$. Next to the dike toe is a canal supplying water to aquaculture ponds of the local residents. Water was pumped from this canal to fill the Simulator during testing. The test location with the vetiver grass slope in Hai Phong is denoted as DS_01. 

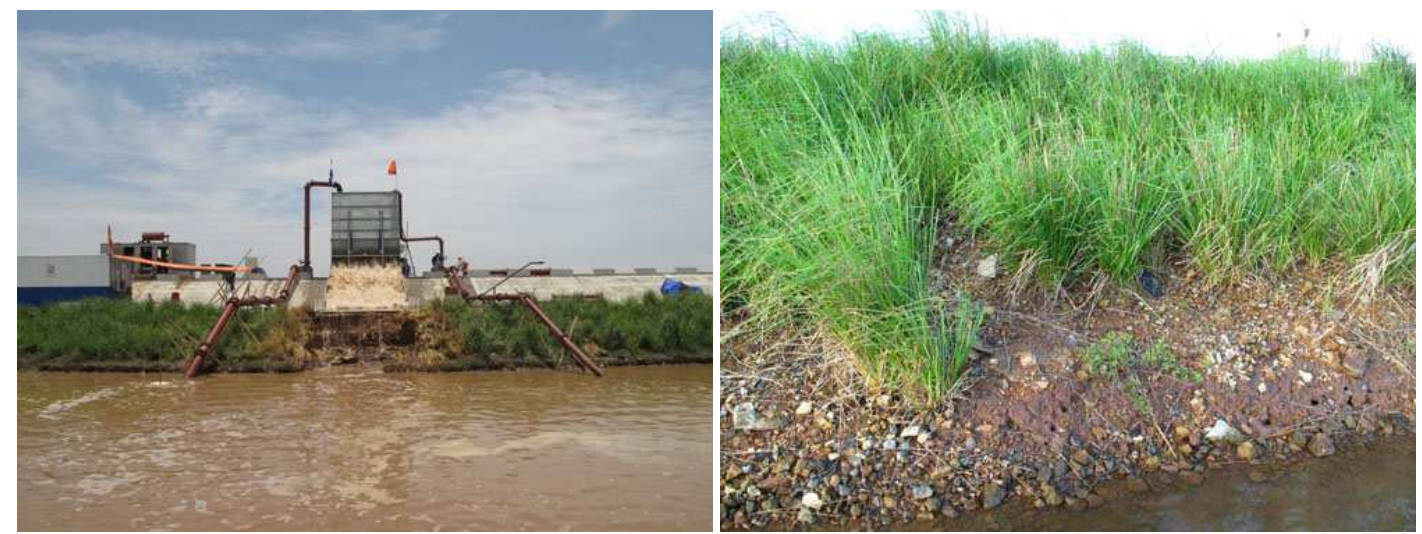

Figure 2. Left: Simulator on dike crest in Hai Phong. Right: lower part of the landward slope was covered with vetiver grass.

Destructive tests were also performed on a dike slope covered with Bermuda grass (Cynodon Dactylon) at the sea dike in Hai Hau - Nam Dinh in Jan 2010. The dike crest level is at $+5 \mathrm{~m}$ above MSL and $4.5 \mathrm{~m}$ wide, paved with concrete of $20 \mathrm{~cm}$ thick. The tested slope is $10 \mathrm{~m}$ in length from crest to toe and the inclination is $1: 3$. The dike toe is about $10 \mathrm{~m}$ in width and is covered with Torpedo grass (Panicum Repens). Parallel to the dike toe is a brackish water canal which could supply water for the pumps. Within $50 \mathrm{~m}$, three sections each $4 \mathrm{~m}$ in width with various slope qualities were tested. These locations are denoted as TL_01, TL_02 and TL_03, respectively.
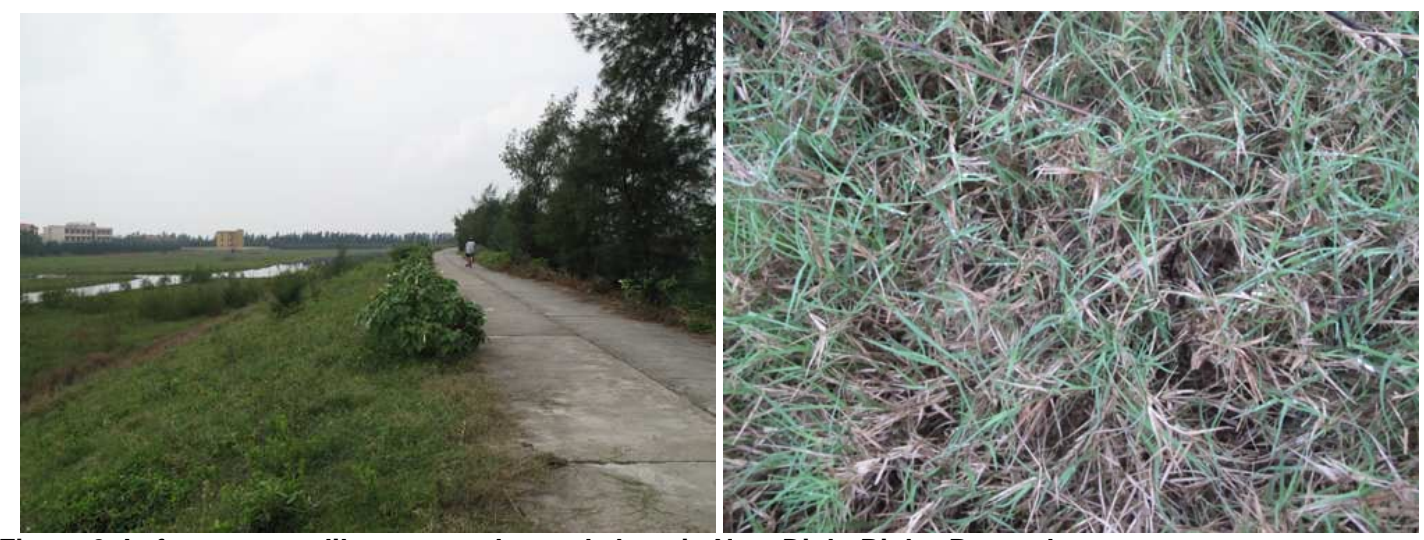

Figure 3. Left: concrete dike crest and tested slope in Nam Dinh. Right: Bermuda grass.

\section{Test conditions}

The wave overtopping resistance of grass slopes was tested with mean discharges increasing from small to large: $10 ; 20 ; 40 ; 70 ; 100$ and 120 1/s per m. Each mean discharge represents a simulated storm lasting for 4 hours which is considered representative for storm characteristics in the North of Viet Nam. Table 1 gives the mean overtopping discharges used at different test locations with corresponding durations. The same wave condition was used in all tests with a significant wave height of $1.5 \mathrm{~m}$ and peak period of $6.0 \mathrm{~s}$. Each simulation of a storm is a distribution of wave overtopping volumes. Figure 4 illustrates the distributions which were calculated with the design wave conditions, for various mean discharges according to Eurotop (2007). The vertical axis gives the overtopping wave volume, $V$, and the horizontal axis gives the number of waves, $N_{w}$, in ascending order. In reality wave overtopping is a random process and for that reason the list of overtopping wave volumes, as shown in Figure 4, was randomized. In order to investigate the development process of damage induced by wave overtopping, every four-hour-storm was split into four sets of 1 hour each. Between successive tests, measurements and observations of the grass slope were carried out. 


\begin{tabular}{|c|c|c|c|c|c|c|c|}
\hline No & Location & 10 & 20 & 40 & 70 & 100 & 120 \\
\hline 1 & TL_01 & 4 hours & 4 hours & 4 hours & 3hours & - & - \\
\hline 2 & TL 02 & 4 hours & $1 \mathrm{~h} 49 \mathrm{~m}$ & - & - & - & - \\
\hline 3 & TL_03 & 4 hours & 4 hours & $2 \mathrm{~h} 20 \mathrm{~m}$ & - & - & - \\
\hline 4 & DS 01 & - & 4 hours & 4 hours & 4 hours & 4 hours & 2 hours \\
\hline
\end{tabular}

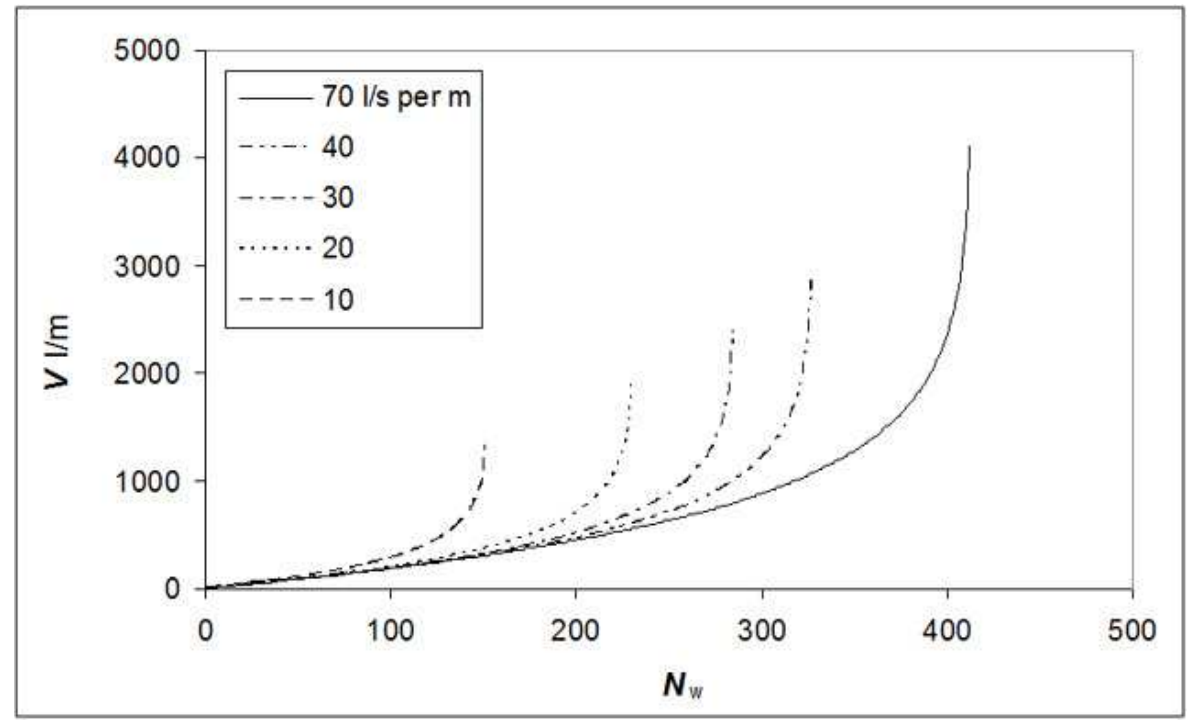

Figure 4. Distributions of overtopping wave volumes with different values of mean overtopping discharge.

\section{FORMATION AND DEVELOPMENT OF DAMAGES}

Comparing profiles and images of grass slopes at different moments, it was found that under attack of overtopping flows, damages could be formed on the slope and at the transition between the dike slope and the dike toe. Corresponding to different position of formation, damages were developing in different shapes such as rectangle, square and trapezoid, see Figure 5. Due to the differences in characteristics of geometry and material including soil and grass the formation and development of damages are described separately as follows.

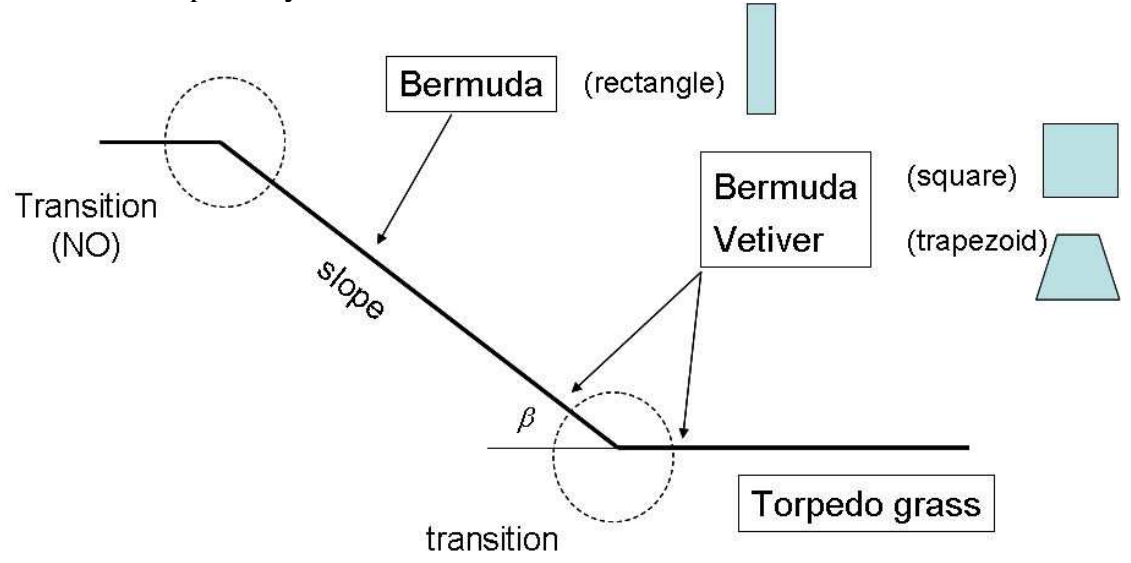

Figure 5. Damage positions and corresponding shapes.

\section{Bermuda grass slope}

It was observed that damage started around small casuarina trees and at the existing holes more than at other points on the grass slope. At the locations of casuarina trees and existing holes, the continuation of the slope was interrupted in both the underneath soil and the top cover of grass. These locations were considered as weak points which were more easily damaged than the intact part of the slope under attack of overtopping flows.

At test location TL_02, damage was first formed at an existing hole, see Figure 6. After 2 hours testing with a discharge of $10 \mathrm{l} / \mathrm{s}$ per $\mathrm{m}$, this damage hole became a deep gully with one side reaching 
the small casuarina which was $7 \mathrm{~cm}$ in diameter. After that, the damage developed rapidly resulting in the collapse of the casuarina and a large hole on the dike slope, see Figure 7.
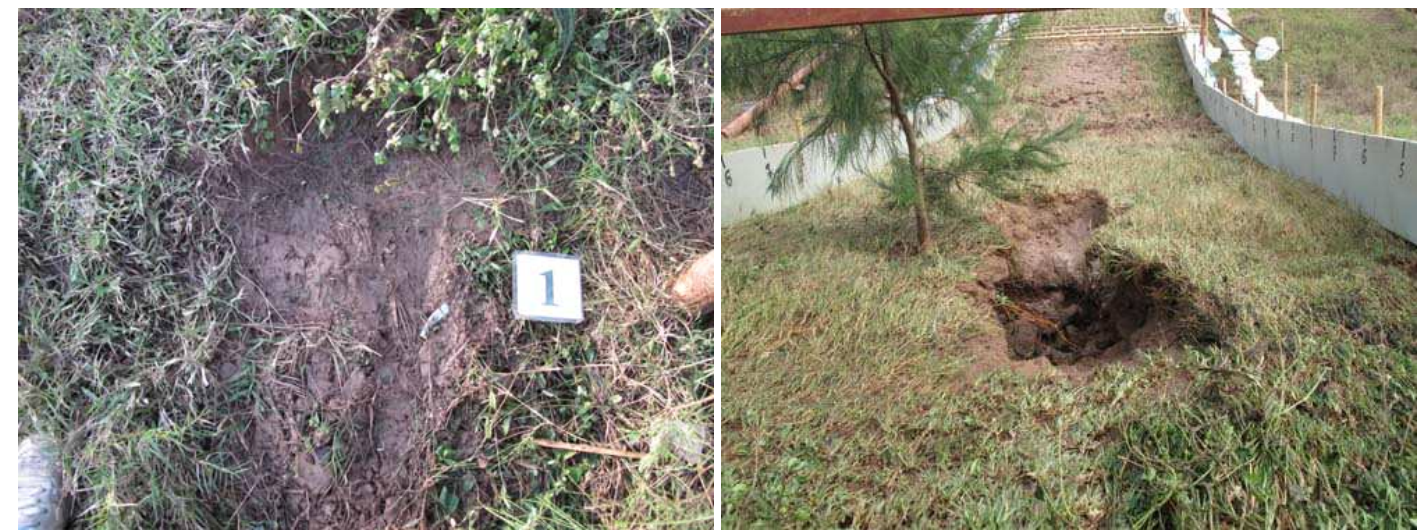

Figure 6. Formation and development of damage on Bermuda grass slope. Left: initial situation. Right: damage was extending to the casuarina root.

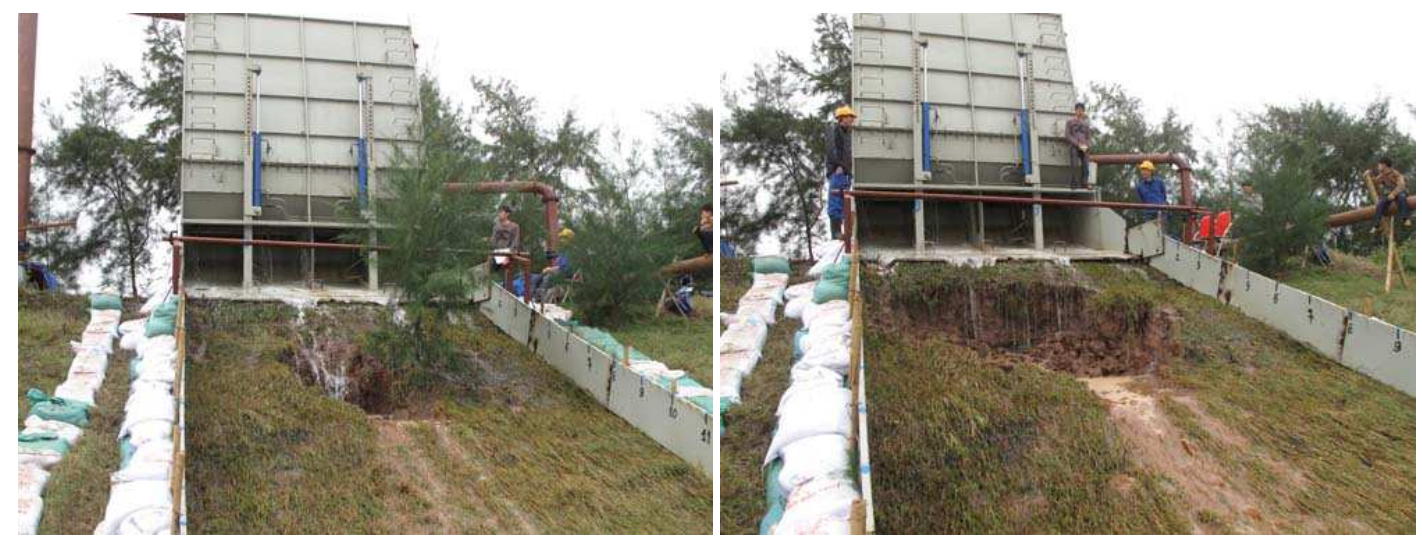

Figure 7. Dike slope after 4 hours of $10 \mathrm{l} / \mathrm{s}$ per $\mathrm{m}$ (left) and after that 30 minutes of $20 \mathrm{l} / \mathrm{s}$ per $\mathrm{m}$, the 7-cmdiameter casuarina collapsed (right).

Under attack of overtopping flows, separate damages could extend to merge into a larger one. Figure 8 shows the situation of a single damage hole and the tendency in which this hole was extending to reach another hole nearby. Later on, the newly formed damage was developing significantly downward in the flow direction. Figure 9 illustrates the damage with rectangular shape after 4 hours of $10 \mathrm{l} / \mathrm{s}$ per $\mathrm{m}, 4$ hours of $20 \mathrm{l} / \mathrm{s}$ per $\mathrm{m}$ and 1 hour of $40 \mathrm{l} / \mathrm{s}$ per $\mathrm{m}$.
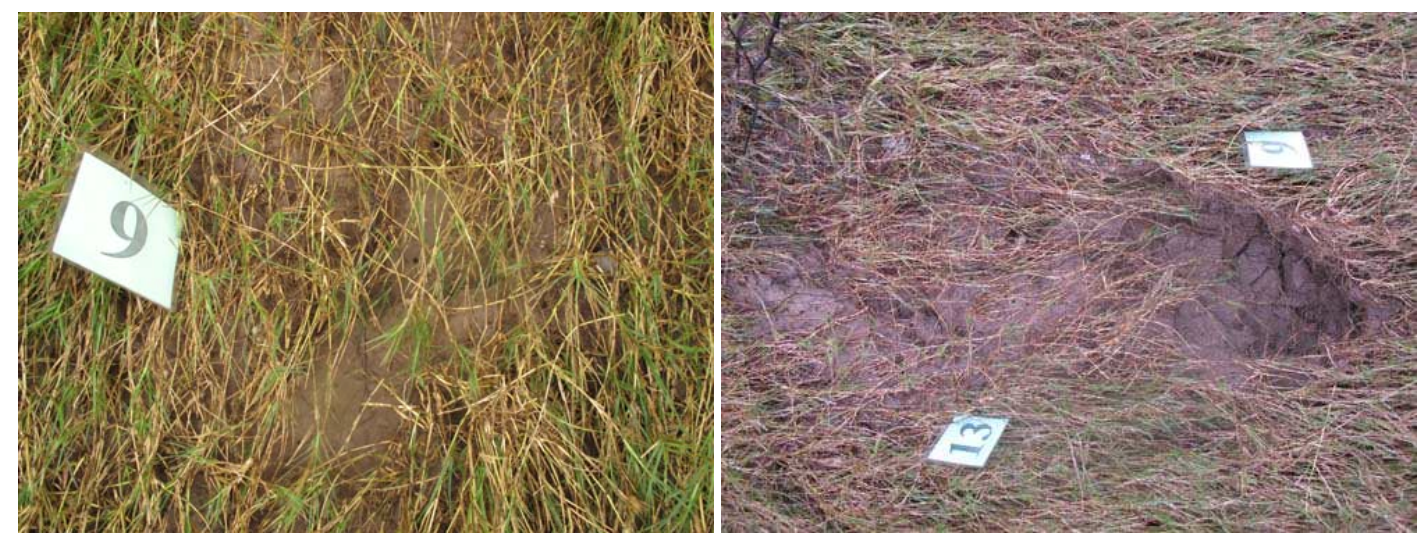

Figure 8. Left: single damage hole after 4 hours of $10 \mathrm{l} / \mathrm{s}$ per $\mathrm{m}$ and 2 hours of $20 \mathrm{l} / \mathrm{s}$ per $\mathrm{m}$. Right: 2 hours extra of $20 \mathrm{l} / \mathrm{s}$ per $\mathrm{m}$, tendency of combining two separate holes close to each other. 


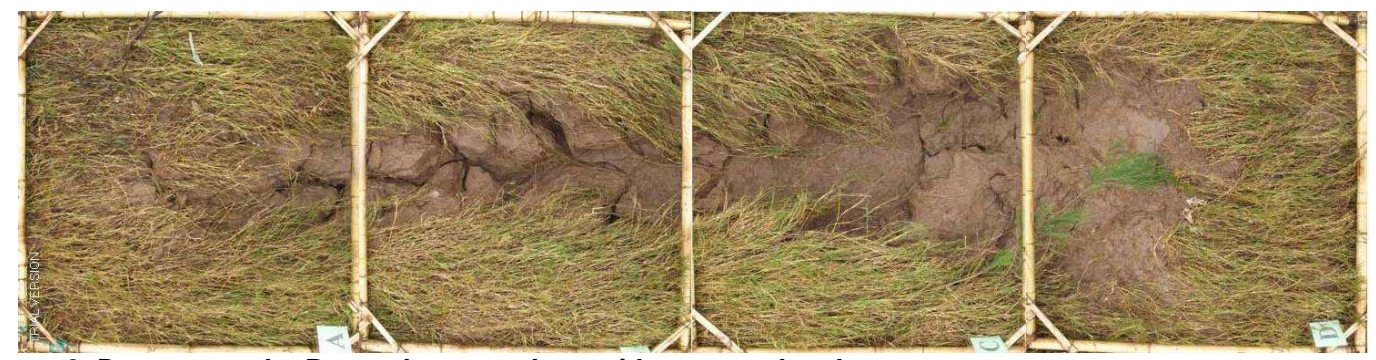

Figure 9. Damage on the Bermuda grass slope with rectangular shape.

At test location TL_01, damages occurred at the transition between the dike slope and the dike toe. The slope was covered with Bermuda grass while the foreland was covered with Torpedo grass. Around the transition, the density of either Bermuda grass or Torpedo grass was lighter compared to the higher part of the slope or further away from the dike toe, see Figure 10. It was covered with a thin mat of grass and the soil at the transition was exposed directly to the attack of wave overtopping flows. Moreover, overtopping flows had to turn direction at the transition to attack the foreland under an angle of $\beta \neq 0$ resulting in a much stronger effective force compared to the situation when flows are parallel to the slope. Damages around the transition had square shapes with similar length and width in the entire duration of testing, see Figure 11. It was recognised that when the damage holes got a certain depth, an amount of water was trapped to act as a buffer against the flow impact.

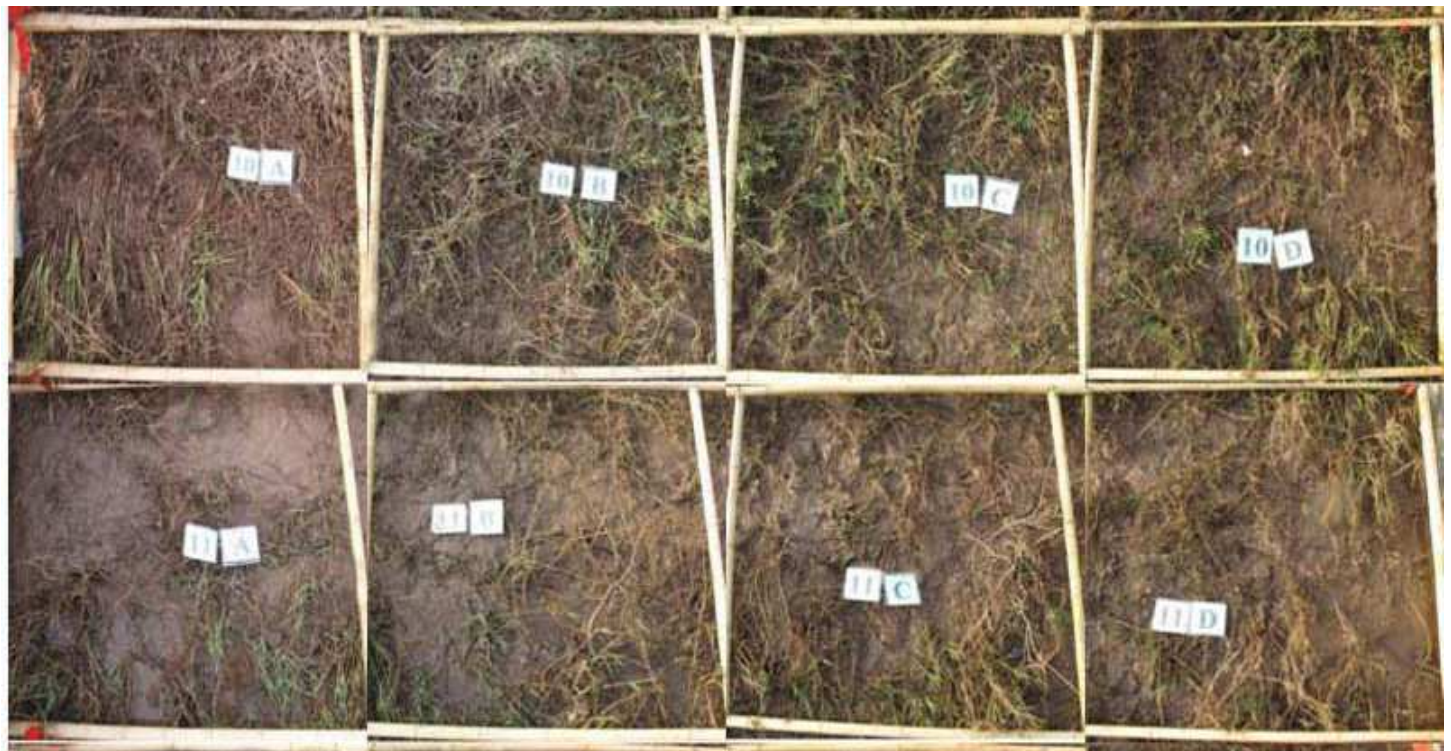

Figure 10. Poor coverage of grass at the transition between the dike slope and the dike foreland.

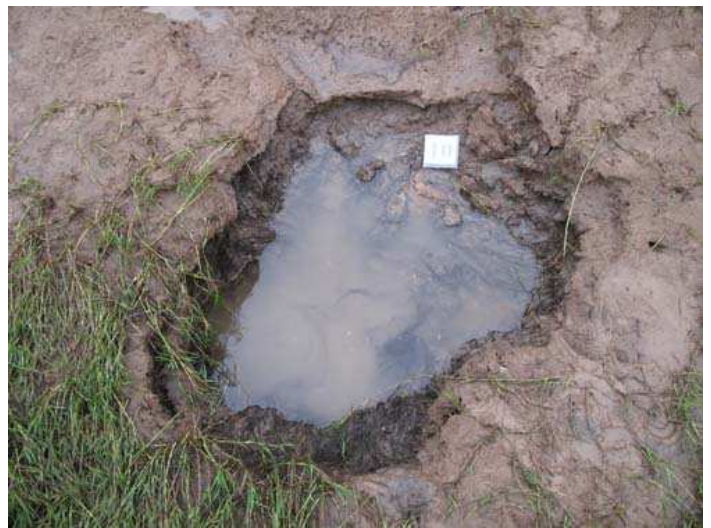

Figure 11. Damage at transition between dike slope and dike toe. 


\section{Vetiver grass slope}

The situation at test location DS_01 was very different due to the vetiver grass and the existence of the inner berm. The berm and the upper part of the inner slope reinforced with concrete were considered to remain intact during testing. Overtopping flow released from the simulator could only affect the lower slope covered with vetiver grass. Figure 12 gives an impression of the water flow flying into the air from the inner berm, and then attacking the dike toe more or less vertically from above. The first row of vetiver clumps next to the concrete berm were first hit by the overtopping flows however these clumps were only forced to lie down and remained intact till the end of the test, see Figure 13. When moving on the slope through separate clumps of vetiver, flow energy and flow velocity were reduced steadily resulting weak flows at the end of the slope. Therefore it is hypothesized that the flying flows from the inner slope caused damage at the dike toe first. Damage developed upward in a trapezoidal shape with large bottom and narrow top as illustrated in Figure 18.
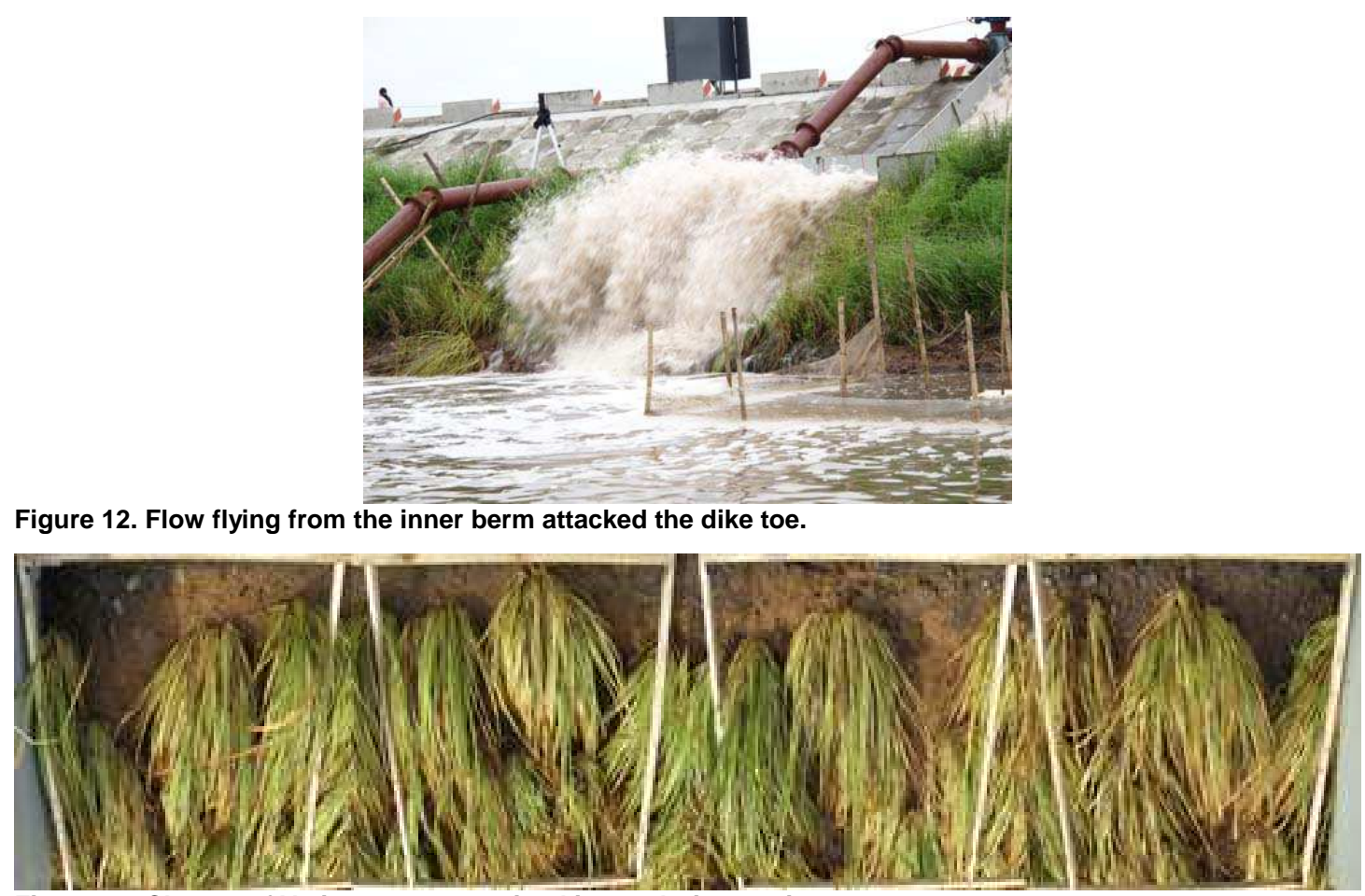

Figure 12. Flow flying from the inner berm attacked the dike toe.

Figure 13. Clumps of Vetiver grass remained intact during testing.

\section{RESULTS OF THE DESTRUCTIVE TESTS}

Test location TL_01

At test location TL_01, the slope surface was regular and evenly covered with Bermuda grass. No visible damage was found before testing. The test was completed after 15 hours of testing with increasing mean wave overtopping discharge from 10 to 70 1/s per m. Figure 14 compares the grass slope at initial situation and at the end of testing. Significant changes can be recognised such as slope profile and grass quality expressed by the coverage and the colour. Damages occurred on the slope and around the transition between the slope and the horizontal toe, the sand core was however not yet reached. 


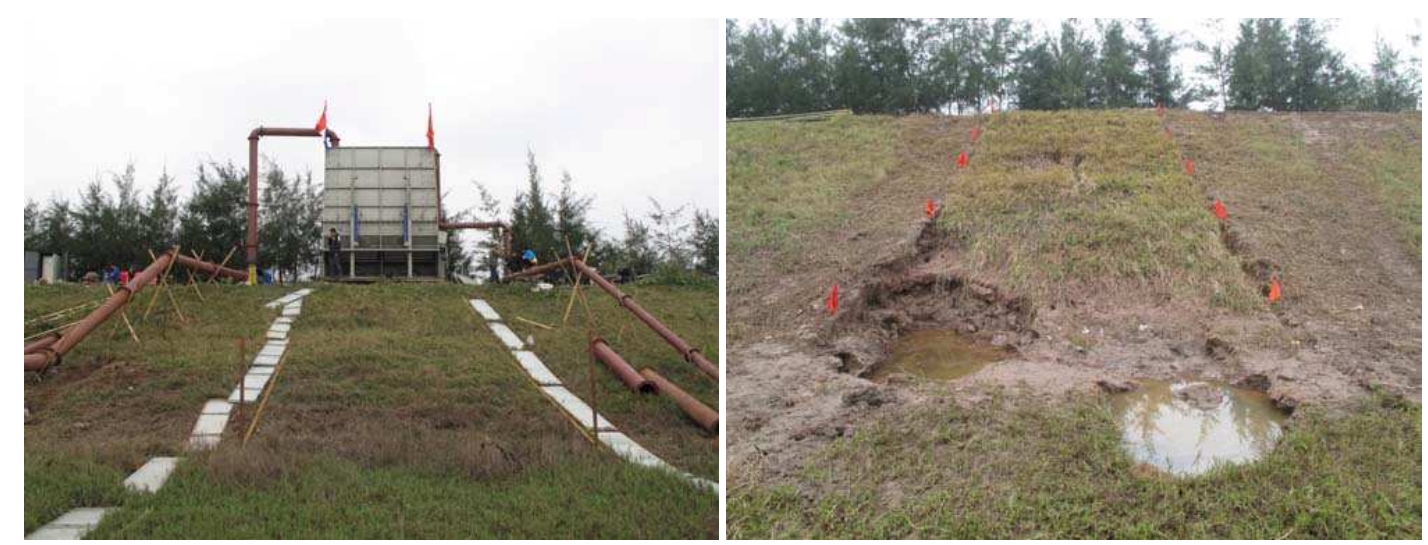

Figure 14. Grass slopes at test location TL_01: initial situation (left) and final result (right).

\section{Test location TL_02}

At test location TL_02, the dike slope was irregular and covered with different kinds of grass such as Bermuda grass and Crabgrass (Hemarthria compressa). A casuarina tree with diameter of $7 \mathrm{~cm}$ was found to exist more or less at the middle of the slope, see Figure 6. After a short time, damage developed significantly around the casuarina. Along the flow direction, maximum erosion dimension was one third of the length of the slope from crest to toe, about $3 \mathrm{~m}$. Maximum depth of the damage was $1 \mathrm{~m}$. The test was finished after 4 hours of $10 \mathrm{l} / \mathrm{s}$ per $\mathrm{m}$ and 50 minutes of $20 \mathrm{l} / \mathrm{s}$ per $\mathrm{m}$. The process of damage development is shown in Figure 15 with slope profiles measured at different moments in time. Location of the casuarina is marked with a green arrow; 0x0 is the initial profile; 10x 4 is after 4 hours of $10 \mathrm{l} / \mathrm{s}$ per $\mathrm{m}$; and 20x30m means after 30 minutes of $20 \mathrm{l} / \mathrm{s}$ per $\mathrm{m}$.

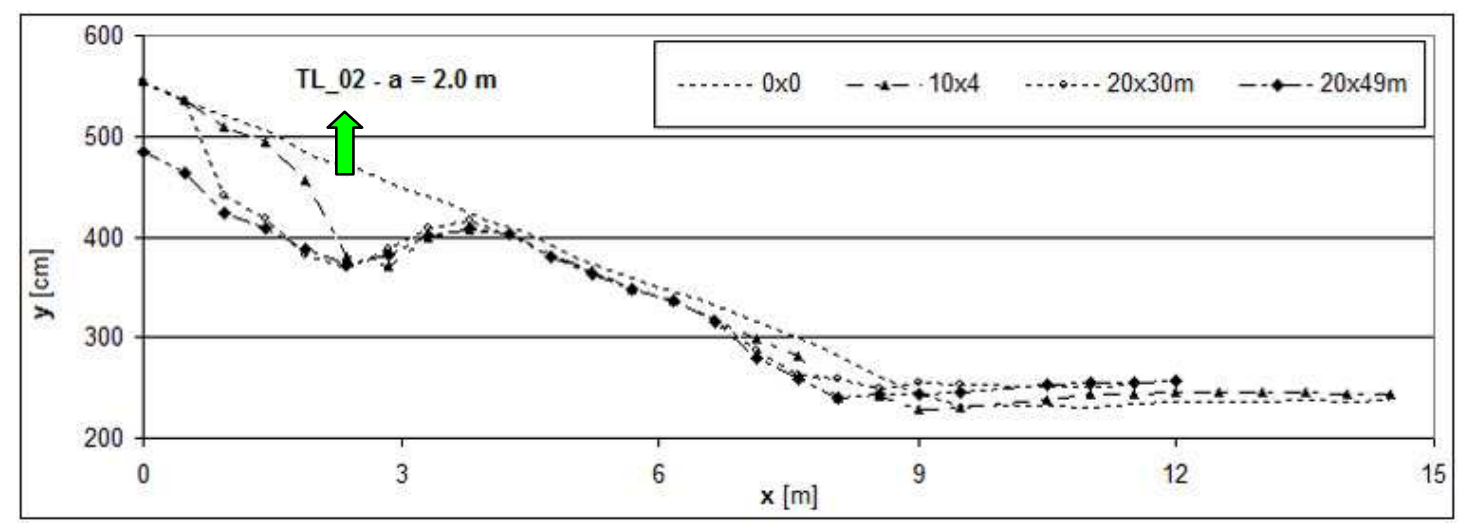

Figure 15. Grass slope profiles under attack of wave overtopping flow, centre cross-section with distance to both side walls of $2 \mathrm{~m}$. Test location TL_02 in Nam Dinh.

\section{Test location TL_03}

The last test location in Nam Dinh, TL_03, was poorly covered with a mix of Bermuda grass and Crabgrass. Some very small casuarinas with diameter of $1 \mathrm{~cm}$ and small holes were found at this slope section before testing. The slope was heavily damaged after more than 10 hours of testing and a maximum discharge of up to $40 \mathrm{l} / \mathrm{s}$ per $\mathrm{m}$. Erosion developed from the dike crest to over half of the slope giving a hole of $5 \mathrm{~m}$ in length and the maximum depth was more than $1 \mathrm{~m}$, see Figure 16. Initial situation and final situation of the grass slope at test location TL_03 are shown in Figure 17. 


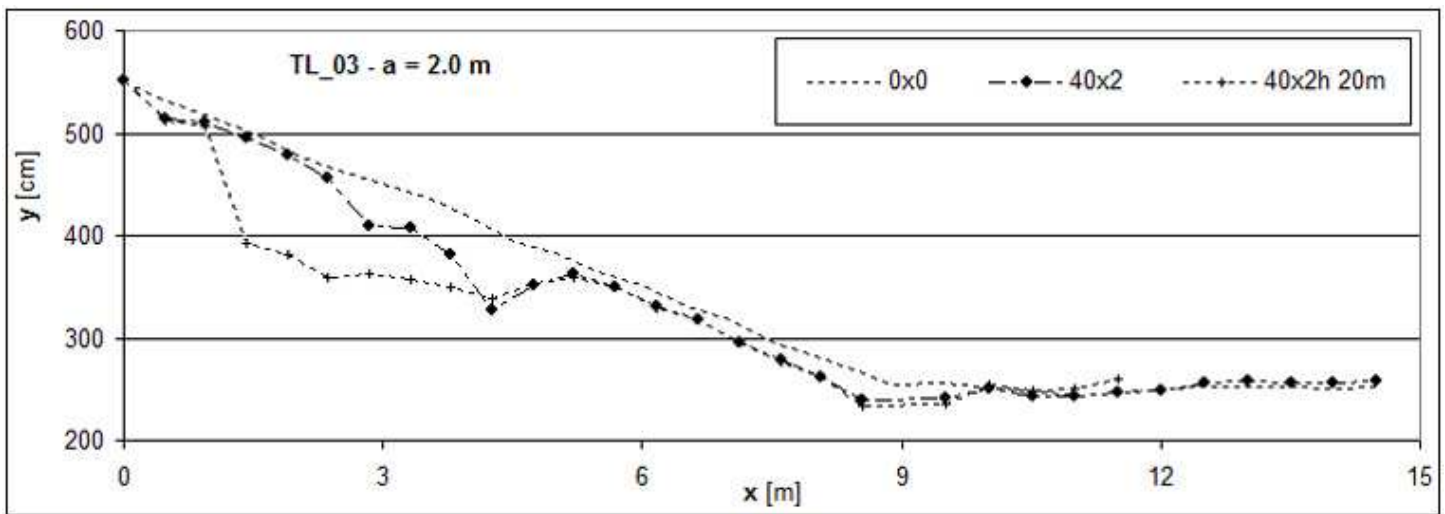

Figure 16. Grass slope profiles under attack of wave overtopping flow, centre cross-section with distance to both side walls of $2 \mathrm{~m}$. Test location TL_03 in Nam Dinh.
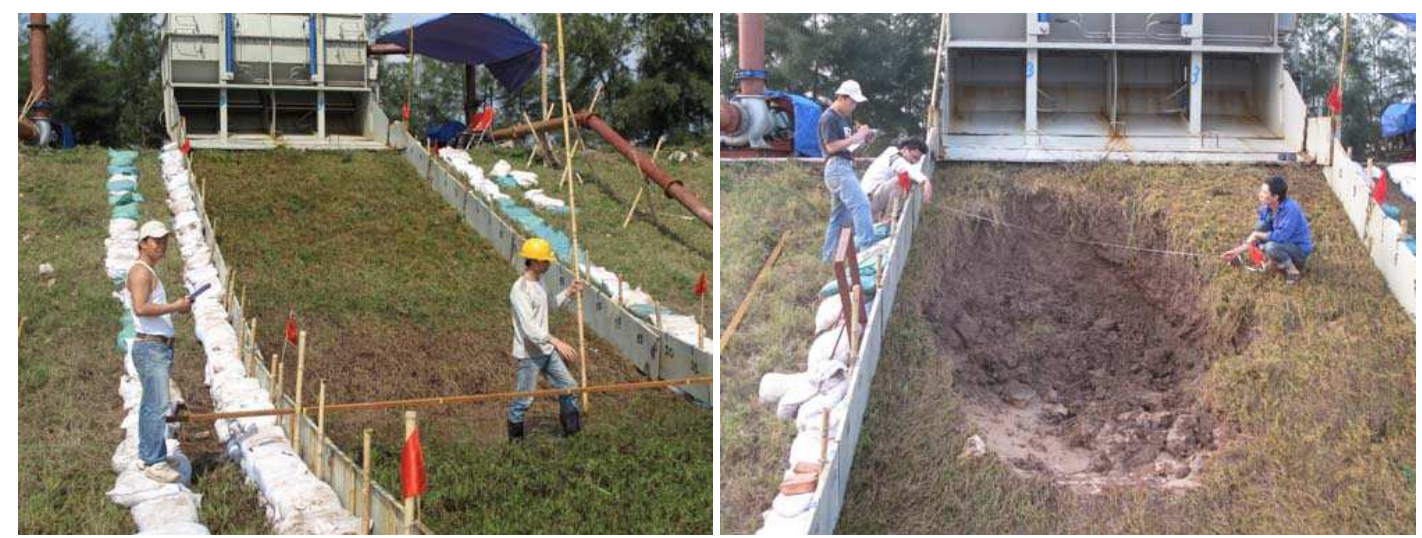

Figure 17. Situations of grass slopes at location TL_03: initial (left) and final (right).

\section{Test location DS_01}

Damages were first recognised between closing clumps near the dike toe after 3 hours testing with a mean discharge of $20 \mathrm{l} / \mathrm{s}$ per $\mathrm{m}$. After 4 hours of $20 \mathrm{l} / \mathrm{s}$ per $\mathrm{m}$ and 1 hour of $40 \mathrm{l} / \mathrm{s} \mathrm{per} \mathrm{m,} \mathrm{some} \mathrm{vetiver}$ clumps were eroded away from the dike slope, see Figure 18, left panel. After 12 hours testing with increasing discharge, no considerable development in the upward direction of the damage was found but the dike toe was steadily eroded. The experiment was finished after 18 hours in total, in which 4 hours of $20 \mathrm{l} / \mathrm{s}$ per m, 4 hours of $40 \mathrm{l} / \mathrm{s}$ per m, 4 hours of $70 \mathrm{l} / \mathrm{s}$ per m, 4 hours of $100 \mathrm{l} / \mathrm{s} \mathrm{per} \mathrm{m}$ and 2 hours of $120 \mathrm{l} / \mathrm{s}$ per $\mathrm{m}$. As can be seen in Figure 18, the lower slope part covered with vetiver grass remained stable, however, the clay underneath was severely eroded.
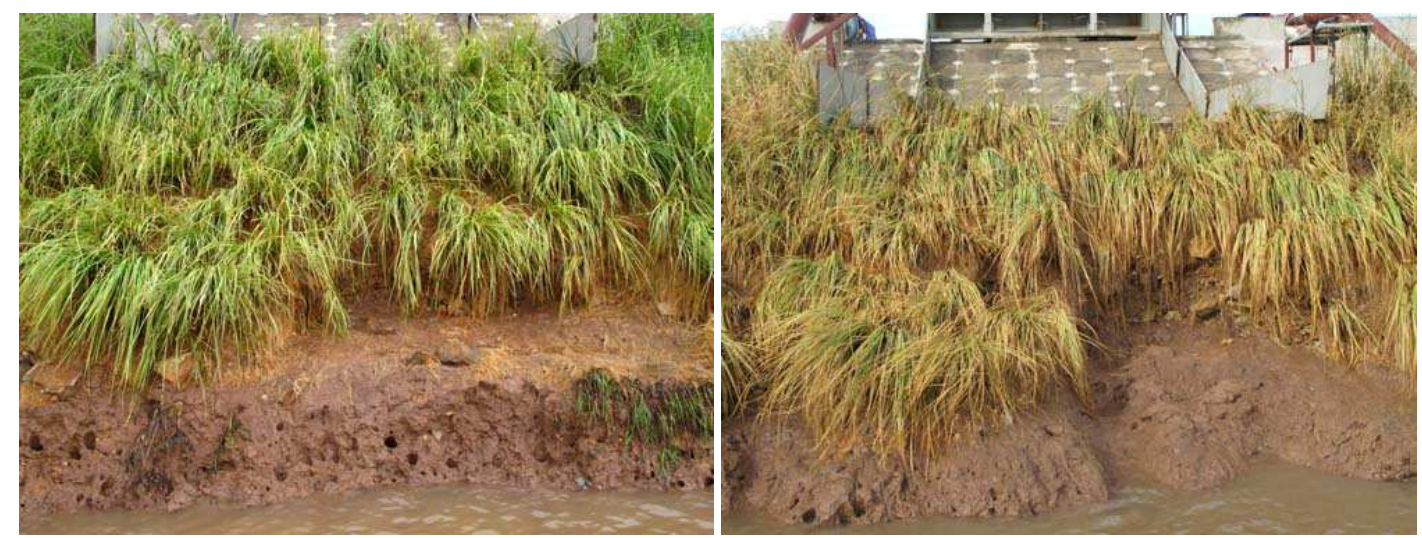

Figure 18. Vetiver grass slope at location DS 01. Left: after 4 hours of $20 \mathrm{l} / \mathrm{s}$ per $\mathrm{m}$ and $1 \mathrm{hour}$ of $40 \mathrm{l} / \mathrm{s}$ per $\mathrm{s}$. Right: final situation. 


\section{MAXIMUM OVERTOPPING DISCHARGE ON GRASS SLOPES}

Within $50 \mathrm{~m}$ of a sea dike stretch in Nam Dinh, strength of the grass slope was tested with the Simulator at three locations. These locations were similar in design and construction. Therefore, capacity of wave overtopping resistance should be more or less the same. However, the maximum mean wave overtopping discharge was found to be significantly different from location to location varying from 20 to 70 l/s per m. The vetiver grass slope in Hai Phong showed a considerable resistance against wave overtopping with a maximum discharge of up to $120 \mathrm{l} / \mathrm{s}$ per $\mathrm{m}$.

Maximum wave overtopping discharges on grass slopes are given in Figure 19. It should be stressed that at these values grass slopes were damaged severely and the dike stability could be threatened.

According to present standard of safety in some developed countries, tolerant overtopping discharge at grass slopes is much lower and in order of litres per second per metre of dike length. For example, Eurotop (2007) suggests a mean allowable overtopping discharge over a grass slope on good clay varying between 1 and 10 l/s per $\mathrm{m}$. It should be noted, however, that these values are not based on testing (as testing was hardly possible without a Simulator) and they are for a safety assessment where or hardly damage is acceptable. There should always be enough safety between start of damage and failure.

From the results achieved in Hai Phong and Nam Dinh, it can be concluded that grass slope is able to suffer wave overtopping. However destructive tests have been limited to two representative crosssections of sea dikes in the North of Viet Nam, it is not possible yet to suggest either damage values or design values of wave overtopping discharges on grass slopes. Figure 19 can be developed further as a tool in assessing capacity of wave overtopping resistance of grass slopes. Not only overtopping discharge, but also the duration of overtopping, should be taken into account. To do so, more destructive tests on different grass slopes are encouraged.

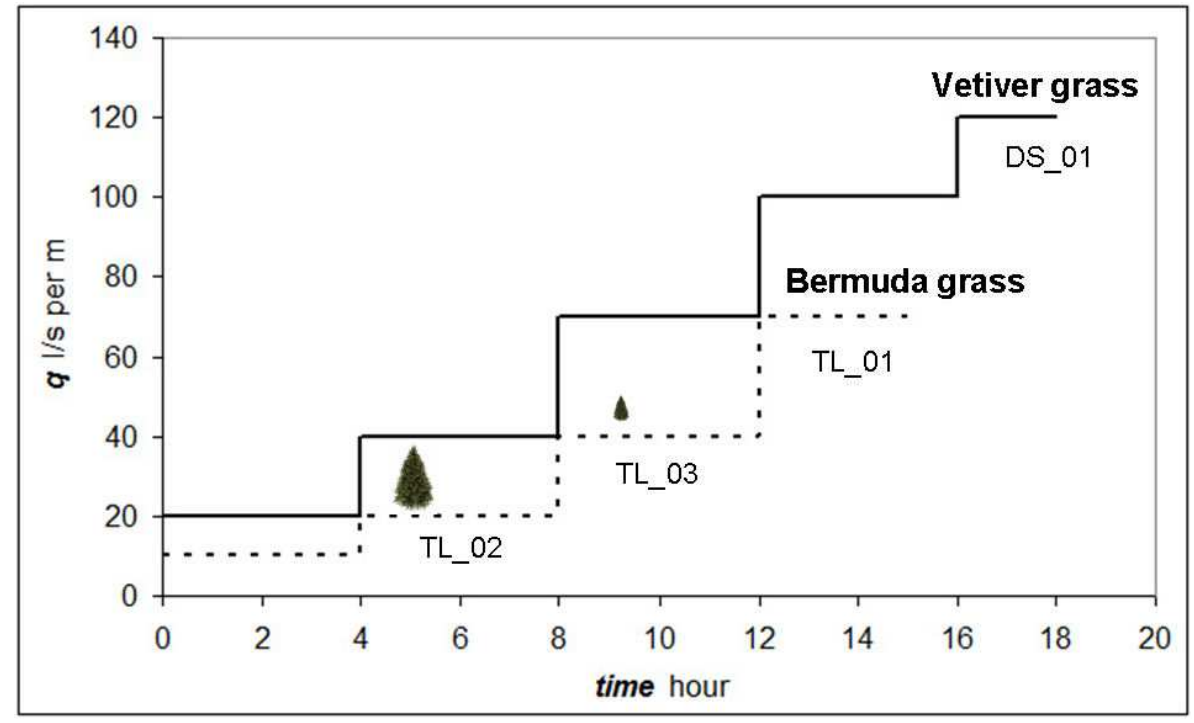

Figure 19. Maximum overtopping discharges on grass slopes.

\section{FURTHER RESEARCH}

Results of the destructive tests with the Simulator help to determine the capacity of wave overtopping resistance at several cross sections along the dike routes of Hai Phong and Nam Dinh. However the number of tests was limited and it is not reasonable to apply the obtained results in either assessing quality of grass slopes or specifying tolerant values of overtopping discharge. The obtained results so far should be used as foundation in investigating the failure mechanism induced by wave overtopping on the landward slope covered with grass.

To understand more about the strength and the weakness of the present sea dikes in Viet Nam and to gain more experience and knowledge to improve the design guideline, more destructive tests are encouraged on different grass slopes. For instance, two typical landward slopes are shown in Figure 20: the first which is steep and short is protected with vetiver grass in Thai Binh; while local grass is planted within concrete frames on the later in Nam Dinh province. For each selected dike section, 
destructive test should be repeated at several locations in order to determine the variation in resistance of the inner slope against wave overtopping.

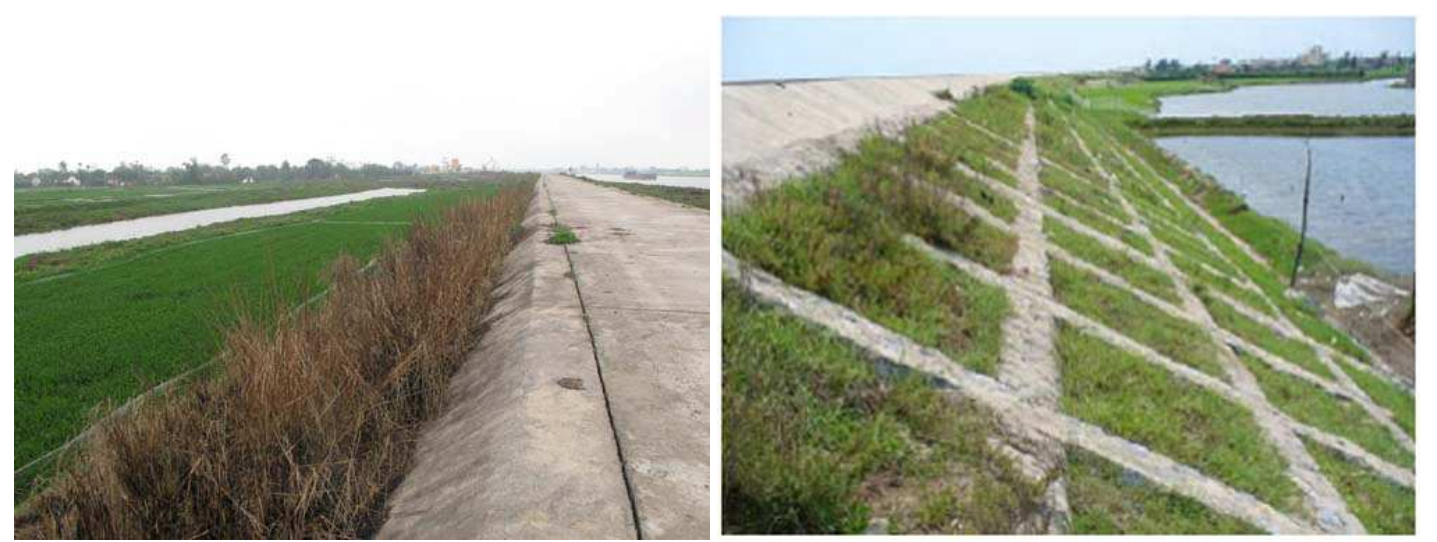

Figure 20. Left: sea dike in Thai Binh with vetiver grass on inner slopes. Right: local grass in concrete frames on Nam Dinh .

\section{ACKNOWLEDGMENTS}

The project "Technical Assistance for Sea Dike Research" which is financed by the Government of the Netherlands is acknowledged for funding to build the Wave Overtopping Simulator and to perform all the destructives tests. The Viet Nam Ministry of Agriculture and Rural Development and the Dike Department of Hai Phong and Nam Dinh province are acknowledged for supporting and cooperating during either preparation or implementation on sites. All the tests were performed by the Faculty of Marine and Coastal Engineering, Water Resources University, Ha Noi, Viet Nam.

\section{REFERENCES}

Bosman, G., 2007. Velocity and flow depth variation during wave overtopping. MSc thesis, Delft University of Technology, Delft, The Netherlands.

EurOtop Manual, 2007. Wave Overtopping of Sea Defences and Related Structures - Assessment Manual. UK: N.W.H. Allsop, T. Pullen, T. Bruce. NL: J.W. van der Meer. DE: H. Schüttrumpf, A. Kortenhaus. www.overtopping-manual.com.

Le Hai Trung, Nguyen Ba Tuyen, Vu Minh Cat and Gerrit Jan Schiereck, 2008. Wave overtopping on Vietnamese sea-dikes. Seventh International Conference on Coastal and Port Engineering in Developing Countries (COPEDEC VII). Dubai, UAE, 2008.

Mai Van Cong, 2010. Probabilistic Design of Coastal Flood Defences in Viet Nam. PhD thesis, Delft University of Technology, Delft, The Netherlands.

Schüttrumpf, H. and van Gent, M. R. A, 2003. Wave overtopping flow at seadikes. ASCE, Proc. Coastal Structures 2003, Portland, USA, pp. $431-443$.

Van der Meer, J.W., Snijders, W., and Regeling, E., 2006. The wave overtopping simulator. ASCE, proc. ICCE 2006, San Diego, 4654-4666.

Van der Meer, J.W., 2007. Design, construction, calibration and use of the wave overtopping simulator. Comcoast, Workpackage 3: Development of Alternative Overtopping - Resistant Sea Defences, Phase 3.

Van der Meer, J.W., G.J. Steendam, G. de Raat and P. Bernardini. Further developments on the wave overtopping simulator. ASCE, Proc. ICCE 2008, Hamburg. pp. 2957-2969.

Van der Meer, J.W., Schrijver, R., Hardeman, B., Van Hoven, A., Verheij, H., Steendam, G.J., 2009. Guidance on erosion resistance of inner slopes of dikes from three years of testing with the Wave Overtopping Simulator. Proc. ICE, Breakwaters, Marine Structures and Coastlines; Edinburgh, UK.

Wave Overtopping Simulator tests in Viet Nam - Two years of testing, Hai Phong and Nam Dinh province. Technical report, 2010. Project "Technical Assistance for Sea Dike Research". Water Resources University, Ha Noi, Viet Nam. 